\title{
Colorectal Benign Granular Cell Tumor
}

National Cancer Institute

\section{Source}

National Cancer Institute. Colorectal Benign Granular Cell Tumor. NCI Thesaurus. Code C96516.

A benign granular cell tumor that arises from the colon or rectum. It usually presents as a mucosal nodule and is detected incidentally by endoscopy. 